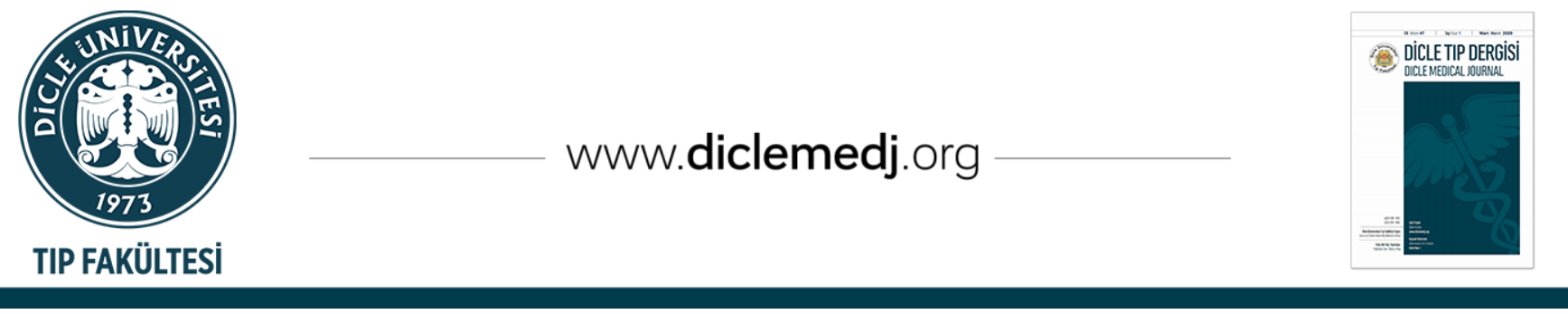

Original Article / Özgün Araştırma

\title{
Clinical Experience In Carotid Body Tumors: Imaging Techniques And Surgical Approaches
}

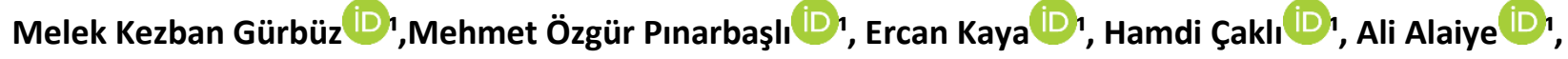 \\ Hülya Kaçar iD2, Erkan Niyazi Özüdoğru iD 1 \\ 1 EskişehirOsmangazi University Medical Faculty of Medicine, ENT Department,Eskişehir,Turkey
}

2 EskişehirOsmangazi University Medical Faculty of Medicine, Pathology Department,Eskişehir, Turkey

Received: 23.01.2020; Revised: 02.05.2020; Accepted: 04.05.2020

\begin{abstract}
Objective: In this article, the imaging techniques and surgical treatment methods used in patients with carotid body tumors were discussed by evaluating the results of our patients with carotid body tumors that we treated surgically.

Method: The information about the patients presented in the article was obtained by retrospectively examining the hospital file records

Results: The mean age of 15 [14 females (93.3\%); 1 male (6.7\%)] patients was52.47 \pm 13.278 (min: 25; max: 69).Only one $(6.7 \%)$ patient had bilateral tumor. The complaint of $12(80 \%)$ patients was swelling in the neck of. In the remaining three $(20 \%)$ patients, the tumor in the neck was detected incidentally.According to the Shamblin classification; five (33.3\%) patients were classified as Type 1, nine (60\%) patients were classified as Type 2, and one (6.7\%) patient was classified Type 3. The mean tumor diameter obtained was $3.053 \pm 0.9342 \mathrm{~cm}(\min : 1,5 \mathrm{~cm}-\max : 4.7 \mathrm{~cm})$, and all histopathological diagnosis were benign paraganglioma. All patients were treated surgically, and no patient has any previous treatment history of carotid body tumor. No significant postoperative permanent morbidity was detected in any of the patients.

Conclusion: Carotid body tumors can be curative treated by surgical excision. However, because of its close relationship with the carotid artery, its surgery is special. Preoperatively meticulously evaluation of patients will increase the success of the surgery and reduce the postoperative complication rate.
\end{abstract}

Keywords: carotid body, tumor, surgical, treatment

DOI: 10.5798/dicletip.748550

Correspondence/Yazıșma Adresi: Melek Kezban Gürbüz, Eskişehir Osmangazi University Medical Faculty of Medicine, ENT Department 26480 TR-

Eskişehir, Turkeye-mail: mkezban@yahoo.com.tr 


\section{Karotis Cisim Tümörlerinde Klinik Deneyim: Görüntüleme Teknikleri Ve Cerrahi Yaklaşım}

\section{Öz}

Amaç: Bu yazıda cerrahi olarak tedavi ettiğimiz karotis cisim tümörlü hastalarımıza ait sonuçlar değerlendirilerek, karotis cisim tümörlü hastalarda kullanılan görüntüleme teknikleri ve cerrahi tedavi yöntemleri tartışılmıștır.

Yöntemler: Yazıda sunulan hastalara ait bilgiler hastane dosya kayıtlarının retrospektif olarak incelenmesi ile elde edilmiştir.

Bulgular: Toplam 15 [14 kadın (\%93,3); bir erkek (\%6,7)] hastanın ortalama yaşı 52.47 \pm 13.278(min: 25; maks: 69) dir. Sadece bir $(\% 6,7)$ hastada bilateral tümör mevcuttur.On iki hastanın (\%80) şikâyeti boyunda şişlik iken, geri kalan üç (\%20) hastada tümör tesadüfen tespit edilmiștir. Shamblin sınıflandırmasına göre beș (\%33,3) hasta Tip 1; dokuz (\%60) hasta Tip 2; bir (\%6,7) hasta ise Tip 3 olarak sınıflandırılmıștır.Patolojik spesmenlerden elde edilen bilgiye göre ortalama tümör çapı3.053 $\pm 0.9342 \mathrm{~cm}(\mathrm{~min}: 1,5 \mathrm{~cm}-\mathrm{maks}$ : 4,7 cm) olup,tüm histopatolojik tanılar benignparagangliomadır. Hastaların tümü cerrahi olarak tedavi edilmiş olup, hiçbir hastanın carotis cisim tümörüne ilişkin daha öncesine ait herhangi bir tedavi öyküsü yoktur.Hastaların hiçbirinde postoperatif kalıcı önemli bir morbidite gelişmemiş olduğu tespit edilmiştir.

Sonuç:Karotis cisim tümörleri cerrahi eksizyonla tedavi edilen, ancak karotis arter ile yakın ilişkisi nedeniyle cerrahisi özellikli tümörlerdir. Ameliyat öncesi hastaların titizlikle değerlendirilmesi cerrahinin başarısını artırır ve ameliyat sonrası komplikasyon oranını azaltır.

Anahtar kelimler: karotis cisimciği, tümör, cerrahi, tedavi.

\section{INTRODUCTION}

Carotid body tumor (CBT) is a rare, mostly benign and slowly growing tumor of the head and neck. Also, it is one of the tumors known as paraganglioma or glomus tumor originating from neuroendocrine cells associated with the sympathetic and parasympathetic nervous system. It is developed from the carotid chemoreceptors located within the adventitia of carotid bifurcation posteriorly and causes painless swelling in that place of origin universally accepted ${ }^{1-3}$. Complaints such as hypertension attacks, headache, abdominal pain, sweating and palpitations seen in some others hormonal active paragangliomas (e.g retroperitoneal paraganglioma) are usually not seen in CBT.

CBT is more common in the middle and older age group, because, as mentioned above, its growth rate is very slow and takes time to be noticed. Additionally, patients with CBT may be diagnosed incidentally when they consult a doctor for another reason, because the tumor is painless and grows slowly. The curative treatment of CBT is surgical excision. However, if the tumor cannot be treated surgically for any reason, radiotherapy may be used ${ }^{1,4}$.

The protection of anatomical adjacent structures near the tumor, principally carotid artery and vagal nerve, which are structures having vital importance and important function for the human body is the most important issue in surgery. Therefore, the evaluation of relationship of tumor with these structures should be done through radiological examinations. The tumor can be classified based on a classification presented by Shamblin ${ }^{5,6}$ in 1971 which reveals the relation between tumor mass and internal and external carotid arteries (Table 1). In this way, the risks associated with the operation can be determined more clearly before the operation. For example, according to this classification, in Shamblin Type 3, internal and external carotid arteries are completely surrounded by the tumor, and the operation of patients with this type of tumor is thought to have a higher risk of bleeding and neurological complications. Consequently, to improve the success of management of patients and tumor, preoperative evaluation of patients with CBT 
should be done meticulously and in detail as in every patient who will undergo surgery.

Table I: Shamblin Classification

\begin{tabular}{|l|l|}
\hline \multirow{2}{*}{$\begin{array}{l}\text { Shamblin } \\
\text { I }\end{array}$} & $\begin{array}{l}\text { Tumors are small and minimally attached } \\
\text { to the carotid vessels }\end{array}$ \\
\cline { 2 - 2 } Shamblin & $\begin{array}{l}\text { Surgical excision usually can be carried } \\
\text { out without difficulty. }\end{array}$ \\
\hline II & $\begin{array}{l}\text { Tumors are usually larger and show } \\
\text { moderate arterial attachment. }\end{array}$ \\
\cline { 2 - 2 } & $\begin{array}{l}\text { Tumors are amenable to careful surgical } \\
\text { removal. }\end{array}$ \\
\cline { 2 - 2 } Shamblin & $\begin{array}{l}\text { Tumors are usually large and incarcerate } \\
\text { the carotids. }\end{array}$ \\
\hline III & $\begin{array}{l}\text { Tumors must be approached with great } \\
\text { considered. }\end{array}$ \\
\hline
\end{tabular}

In this paper, we presented our preoperative evaluation strategies and surgical outcomes of patients with CBT by discussing with the literature knowledge.

\section{METHODS}

The study was approved by local Ethics Committee with the number "19.06.2017/ 08".

The files of patients who were surgically treated with CBT diagnosis between the years 2000 and 2017 in our clinic were reviewed retrospectively. Demographic data, medical history, clinical and radiological findings, applied surgical technique, surgical complications, treatment outcomes and pathology reports of patients were recorded. Tumors were classified according to Shamblin classification5 (Table 1). Patients followed without surgery, patients receiving radiotherapy, patients without definitive pathology report, and patients with insufficient access to information were not included in the study.

\section{RESULTS}

As a result of the examination of the files, 15 [14 females $(93,3 \%) ; 1$ male $(6.7 \%)]$ patients were included in the study according to inclusion criteria. Patients were between 25 and 69 years of age and the mean age was $52.47 \pm 13.27$. Nine (60\%) patients were referred to our clinic from another medical center with a preliminary diagnosis of CBT. It was found that one (6.7\%) patient had bilateral, the other 14 (93.3\%) patients had unilateral tumor in the neck; and $10(66.6 \%)$ tumors were located in the left side, five $(33.3 \%)$ tumors were located in the right side of the neck. The complaint of $12(80 \%)$ patients was swelling in the neck of. In the remaining three $(20 \%)$ patients, the tumor in the neck was detected incidentally. Information about radiological examinations and interventional radiological procedures used for evaluation of tumor before surgery is presented in Table 2 (Figure 1,2 and 3).

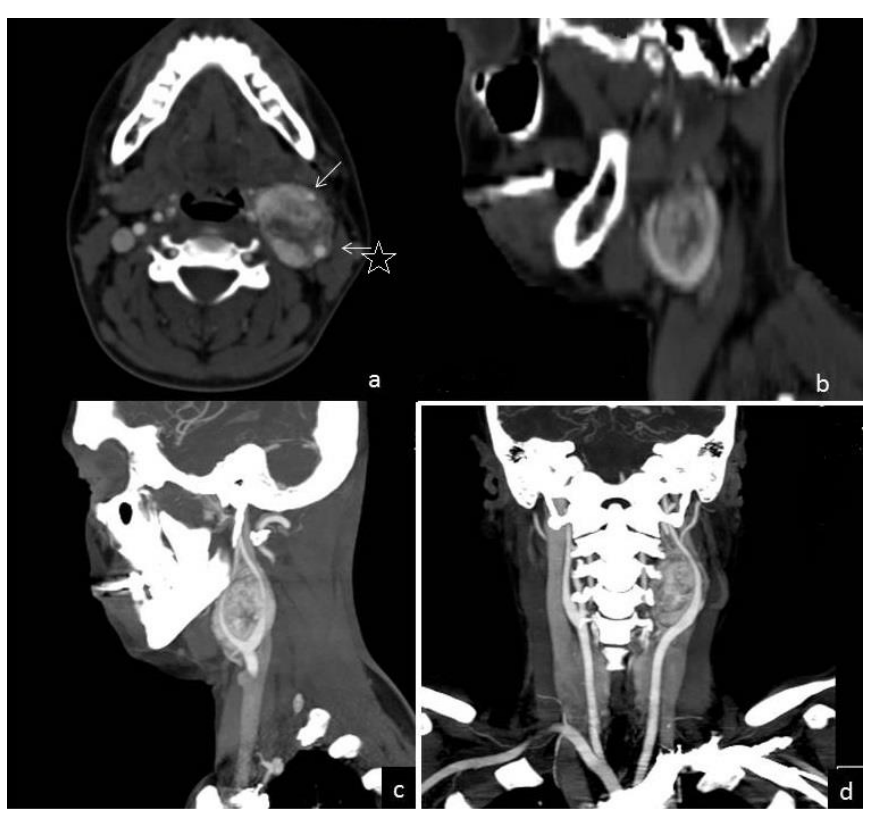

Figure 1: CT angiography images, a case with left CBT.

(a) In the axial image, it is seen that the mass located in the bifurcation separates internal (starry arrow sign) and external (arrow sign) carotid artery. (b)Sagitall reconstructed image, the 
mass separates the branches of the carotid. (c and d) In sagittal and coronal plane, maximum intensity projection technique is used to determine the relationship of the mass with carotid branches.

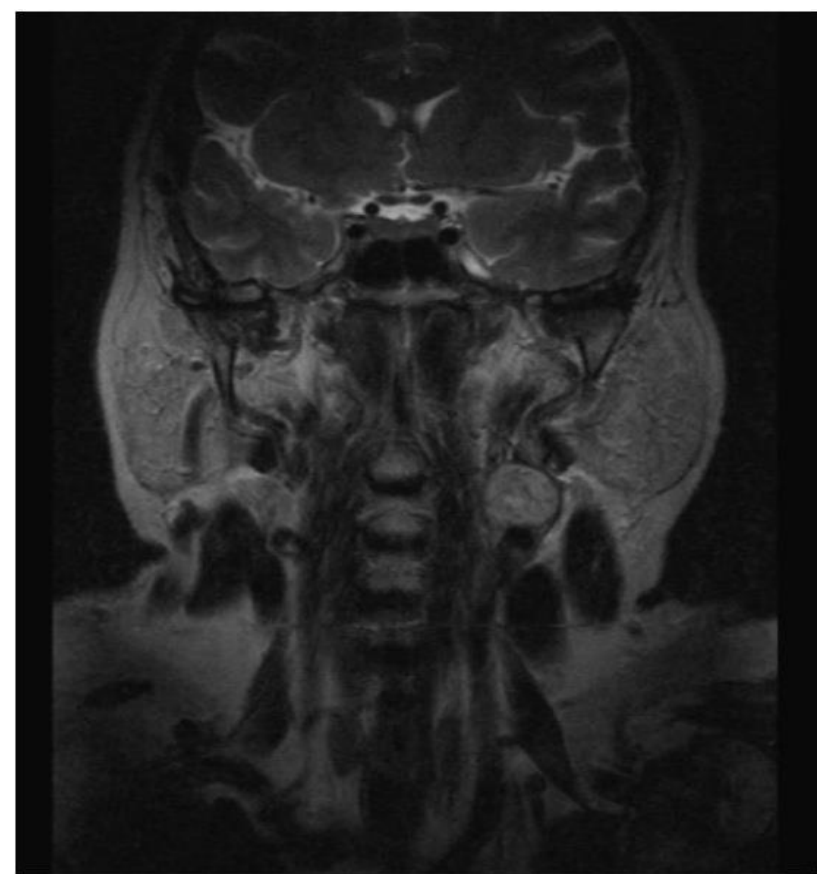

Figure 2: MRI image of an another case having left CBT.

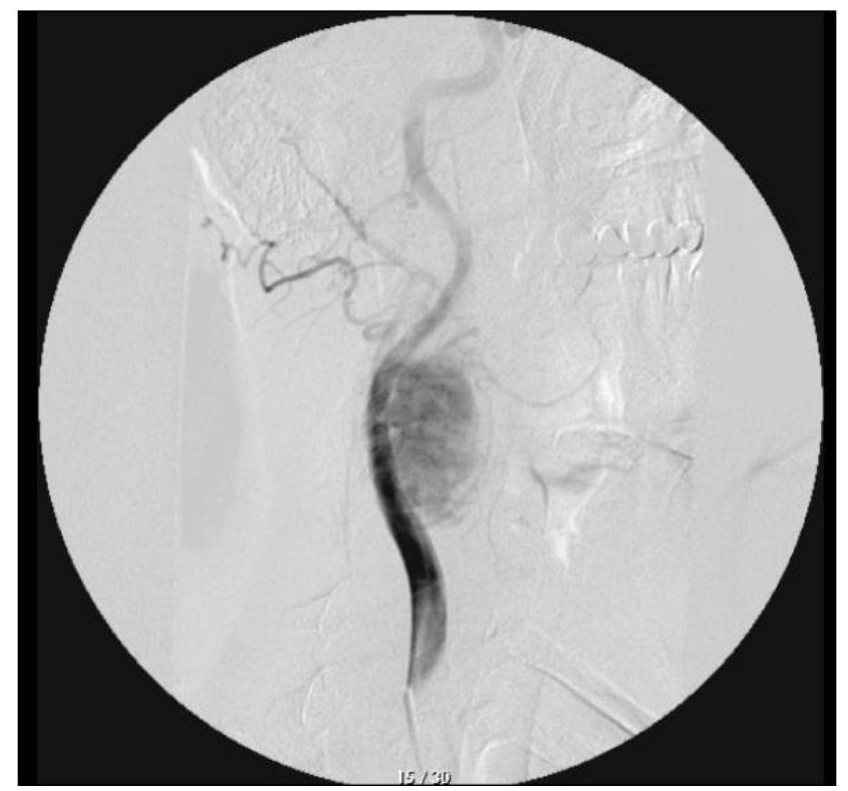

Figure 3: Angiography image, a case with right CBT.
Table II: Preoperative radiologic examinations and interventional radiological procedure

\begin{tabular}{|l|c|}
\hline Type of examination and procedure & Number of patient (\%) \\
\hline Doppler USG & $6(40)$ \\
\hline CT & $9(60)$ \\
\hline MRI & $9(60)$ \\
\hline DSA & $9(60)$ \\
\hline Preoperative embolisation & $2(13.3)$ \\
\hline Baloon oclusion test & $2(13.3)$ \\
\hline
\end{tabular}

According to the Shamblin classification, five $(33.3 \%)$ patients were classified as Type 1 , nine (60\%) patients were classified as Type 2 and 1 patient as Type 3 . None of the patients had excretion of catecholamine in a 24-hour urine test collected to evaluate whether tumors are hormonally active or not. The abdomen of all patients were scanned by abdominal CT in terms of additional paraganglioma, and none of the patients had additional adrenal and extra adrenal paraganglioma in the abdomen .The mean tumor diameter obtained from pathology report results was $3.053 \pm 0.9342 \mathrm{~cm}(\min : 1,5$ $\mathrm{cm}$ - max:4.7 cm), and all histopathological diagnosis were benign paraganglioma. In no specimen, pathological lymph node that can be evaluated in favor of metastasis was detected adjacent to the tumor. Malign transformation was not seen in any of tumors. Six (40\%) of tumors had 1-3 mitosis in $10 \mathrm{HPF}$ and the rest had rare mitosis. Ki-67 proliferation index ranged between 1-10\% (mean 3.3\%). Other pathological features of the tumors are presented in Table 3.

Table III: Pathologic features of tumors

\begin{tabular}{|l|c|}
\hline Pathologic features & Number of tumors (\%) \\
\hline Vascular invasion & $7(46.7)$ \\
\hline Foca lnecrosis & $2(13.3)$ \\
\hline Capsular invasion & $3(20)$ \\
\hline Perineuralinvasion & - \\
\hline
\end{tabular}


In all patients, the tumor was totally removed without leaving residual tissue and mortality. During tumor removal, in two (13.3\%) patients, external carotid artery has been ligated and in other two $(13.3 \%)$ patients carotid communis artery injury has been occurred which was under control with primary repair. One (6.7\%) of patients with carotid communis artery injury had hemiparesis spontaneously recovered within a few hours postoperatively. Additionally, during the operation, the tumor was found to be attached to vagal nerve in two (13.3\%) patients. The vagal nerve was sacrificed in these two patients in surgery. So, these patients had a unilateral permanent vocal cord paralysis postoperatively. Besides, as a complication, in one $(6.6 \%)$ patient, it was found to have developed hematomas with spontaneous remission in follow-up. No recurrence was detected in any of patients during the mean follow-up period of $2.80 \pm$ 1.65(min:1- max:7) years.

\section{STATISTICAL ANALYSIS}

The obtained data were evaluated in the computer environment by using İBM-SPSS 21.0 package program. Since the clinical experience was shared with retrospective data, no specific statistical method was used.

\section{DISCUSSION}

The diagnosis of each disease, it is necessary to know the history and physical examination findings which provide helpful clues in diagnosing the disease in order to use the technologic diagnostic tools correctly and without abuse that are developing rapidly every day. These clues for CBT that facilitate its distinction from other neck mass is shown in Table 4. All of these clues also overlaps with the findings of our patients. Namely, all of our patients were adult; only $1(6.7 \%)$ of our patients had bilateral tumor; none of our patients had signs of tumor pressure or catecholamine discharge; and in the majority
$(12=\% 80)$ of our patients, the first complaint was painless swelling in the neck.

Table IV: The clues for CBT facilitate its distinction from other neck tumoral mass

\begin{tabular}{|c|c|}
\hline $\begin{array}{l}\text { The complaint of the first application is } \\
\text { usually a slowly growing painless mass }\end{array}$ & \\
\hline \begin{tabular}{|l} 
Neckmass; \\
$\begin{array}{l}\text { İs located in the direction of } \\
\text { carotid bifurcation in the neck }\end{array}$ \\
$-\quad$ is usually unilateral
\end{tabular} & \\
\hline $\begin{array}{l}\text { is not able to move vertically on } \\
\text { palpation (Fontaine sign) }\end{array}$ & $\begin{array}{l}\text { because the mass is } \\
\text { conjoined to the } \\
\text { carotid sheet }\end{array}$ \\
\hline Patients are usually adult & $\begin{array}{l}\text { because it grows very } \\
\text { slowly and is } \\
\text { asymptomatic until it } \\
\text { reaches a certain size. }\end{array}$ \\
\hline $\begin{array}{l}\text { As tumor grows; symptoms such as } \\
\text { dysphagia, odynophagia, otalgia and } \\
\text { pulsatile tinnitus due to compression of } \\
\text { the vascular and peripheral structure, } \\
\text { and symptoms associated with cranial } \\
\text { nerve paralysis due to compression of } \\
\text { cranial nerves }(9,10,11 \text { and } 12 \text {. Cranial } \\
\text { nerve) may occur }\end{array}$ & \\
\hline $\begin{array}{l}\text { If patient has an additional a } \\
\text { paraganglioma in surrenal gland; } \\
\text { symptoms such as flushing, palpitation } \\
\text { and hypertension attack smay ocu }\end{array}$ & $\begin{array}{l}\text { due to catecholamine } \\
\text { discharge }\end{array}$ \\
\hline
\end{tabular}

In practice, computerized tomography (CT) and magnetic resonance imaging (MRI) are the most commonly preferred diagnostic radiological methods for patients with CBT and provide enough information about the tumor in relation to the carotid artery and other surrounding structures with the images taken by arterial phases. The other diagnostic methods are digital subtraction angiography (DSA) and scintigraphy. Scintigraphy (using metaiodobenzylguanidine and octreoscan) is not routinely preferred, but it can be useful to assess paragangliomas in other areas of the body. With angiography techniques, tumor can be embolized and the competence of the contralateral carotid system can be investigated by balloon occlusion test ${ }^{7-9}$. With all these radiologic examinations, most often with $\mathrm{CT}$ or MRI, the type of tumor is determined according 
to Shambling classification so that tumor's suitability for operation and possible risks related to the surgery can be specified ${ }^{5}$. As a result, patients and their relatives can be clearly informed about the treatment of the disease. In our clinic, as a first choice, a simple noninvasive technique, Doppler ultrasonography (USG), is requested in a patient suspected of having a diagnosis of CBT by history and physical examination of patient. In this way, simple information about the structure of mass in the neck is obtained and the preliminary diagnosis is clarified. In fact, this is our general approach to patients who admitted to our clinic with a complaint of mass in the neck. When the diagnosis of CBT is confirmed with USG, to reveal information about the mass in relation to the carotid artery and other surrounding structures, firstly, we prefer CT, because it is easier examination to access and to adapt for patient than MRI with the fast imaging technique. Nowadays, thanks to technological advances in radiology, in large tumors in which the relationship of tumor with carotid is not demonstrated, the images taken by arterial phases with CT or MRI (images of CT or MRI angiography technique) may be useful and sufficient, so that the tumor does not need to be additionally evaluated with DSA to obtain information about the blood pattern of the tumor. All patients with MRI in our series were referred to us from the external center. However, three of these patients actually had CT at the time of admission, and their CT had not enough quality for preoperative evaluation, especially in terms of assessment of the association of tumor with carotid. To avoid exposure to radiation again, these patients had to be evaluated with MRI performed in our radiology department, although our classical evaluation method in CBT is CT. For this reason, it would be more appropriate for physicians who do not have the possibility to treat such patients as CBT to refer these patients to an upper center by making a pre-diagnosis with simple noninvasive techniques as possible such as USG. In this way, unnecessary additional tests and time loss can be prevented.

In our clinic, DSA is performed only in patients who are scheduled for preoperative embolization or balloon occlusion test. However as seen on Table 2, DSA (Figure 3) was performed on nine $(60 \%)$ of 15 patients in our series and only two $(13.3 \%)$ of these patients were embolized and performed balloon occlusion test. The reason DSA is made so much in our series is that during that time, the arterial phase technique could not be successfully implemented during CT withdrawal in our hospital. Moreover, preoperative embolization, which is a controversial issue in patients with CBP in the literature, is no longer preferred in our clinic today. Because we think that embolization does not reduce bleeding in these patients. On the contrary, as an invasive technique it may cause some additional problems in patients, such as cerebral embolism. In addition, the possibility of hemorrhage can be minimized if the patency of the tumor is well evaluated and patience and carefulness is demonstrated during the dissection of the tumor. Besides, Nettervilleet al. ${ }^{10}$ reported that preoperative embolization could initiate the inflammatory process in the treatment area, thereby the risk of carotid artery injury could increase during tumor excision. Kakkoset al. ${ }^{11}$ also suggests preoperative embolization for Shamblin Type 3 tumors extending to the base of the skull. Two patients who were preoperatively embolized in our series were Type 2 according to Shamblin classification, and embolization of both patients was completed without any problems. The operation of both patients was performed within 48 hours before collateral vessels develop as suggested in the literature. However, intraoperative carotid rupture developed in both patients, and vascular repair was performed successfully by a cardiovascular 
surgeon. Even though we cannot make a statistical comment because of the low number of patients, of those patients may be related to the comments made by Netterville 10 and his colleagues as mentioned above. And, we can conclude that embolization may have been unnecessary in both of our patients when we evaluated this result according to the comment of Kakkos ${ }^{11}$ and his colleagues mentioned above, because both of our patients were classified as Type 2 according to the Shamblin classification. We perform a balloon occlusion test in patients classified as Type 3 during DSA, especially in patients whose tumors have a risk to not been able to remove without the carotid artery ligation during surgery, like as in two $(13.3 \%)$ patients in this series. Carotid artery by-pass surgery is one of the surgical choice in type 3 CBT. Instead of carotid ligation by-pass can be best choice for postoperative complications. Therefore, patients discussed with vascular surgeon pre-operatively. Although some authors have reported that they have performed balloon occlusion test on all patients, regardless of Shamblin classification. With this test, the blood flow of the carotid artery surrounding by the tumor is stopped in a controlled manner and contrast injections are made with another catheter placed in contralateral carotid artery. In this view, the Willis polygon is evaluated, the competence of the contralateral carotid artery system is investigated, and it is determined whether the patient will tolerate carotid artery ligation. As a result, patients and their relatives can be informed more precisely and more accurately about the consequences of carotid artery ligation. So, the physician may feel more secure and patients will be less afraid of surgery because of the possible of poor results of carotid artery ligation such as hemiplegia or $7,9,10,11,12$ th cranial nerve paralysis. Consequently, the number of patients who prefer stereotacticradiotherapy that is not the curative treatment in CBT because of their fear of surgery, will decreased. As is known, radiotherapy can only slow the growth rate of the tumor, and it is recommended for patients thought to develop a significant morbidity in the postoperative period, patients with unresectable tumor, patients who do not want to be operated and patients having risk for general anesthesia. Therefore, it is important to determine the resectability of the tumor and the risks of operation in detail so that patients with CBT can be safely guided to surgical treatment. In addition, patients who cannot overcome their fears about surgical treatment should be told that radiotherapy is not a simple, innocent treatment. And most importantly, if the surgeon is confident in his/her technique and experience in CBT surgery, he/she must be able to it feel to his/her patient.

In our clinic, the technique called "INTEX" which is recommended by Rao et al. 12 is used during surgery. In this technique, total dissection of the tumor is completed after the carotid artery, internal carotid artery and external carotid artery are dissected subadventically and the arteries are controlled by vascular sling (Figure 4).

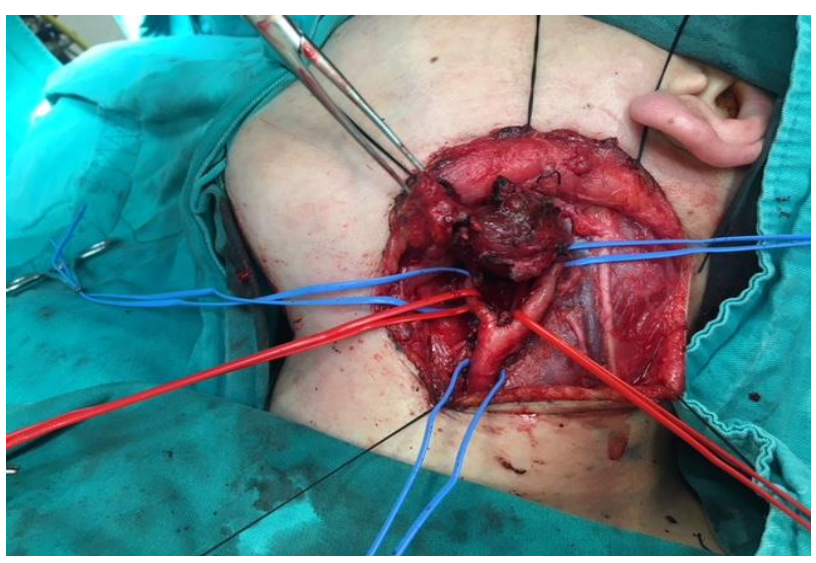

Figure 4: Operation image, a case with left CBT.

CT images of this patient were shared in Figure 1

With this technique, bleeding control and dissection of the tumor can be made more easily. In addition, reactive lymphatic tissues are usually observed around the tumor and are included in the specimen (Figure 5). 


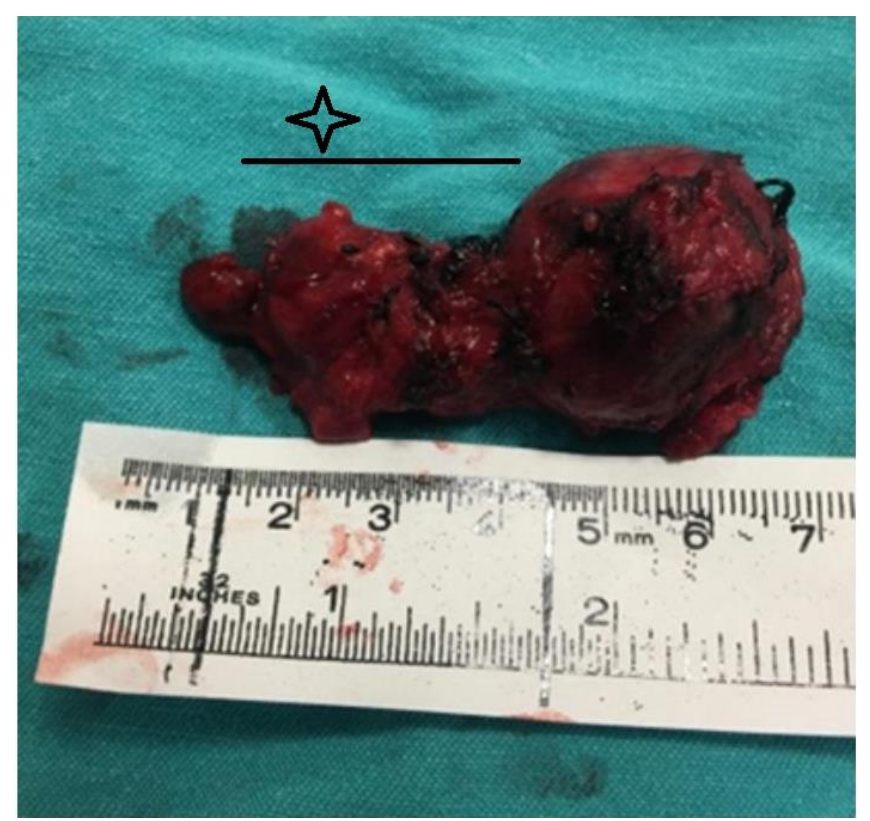

Figure 5: Spesmen image associated with figure 4

Star sign shows reactive lymphoid tissues.

The feared complication of surgical treatment is the development of CVO, permanent hemiplegia and cranial nerve palsy $\left(7,9,10,11,12^{\text {th }}\right.$ cranial nerve) due to carotid artery clamping to control intraoperative bleeding or carotid artery ligation to remove the tumor. The rate of persistent cranial nerve injury after CBT operations was reported by Fruhmann et al ${ }^{13}$., by Kruger et al..$^{14}$ and by Gad et al. ${ }^{15}$ as $20 \%$;11$20 \%$ and $17 \%$, respectively. None of our patients also developed permanent hemiplegia and cranial nerve paralysis as complication. In two $(13.3 \%)$ patients, who developed permanent unilateral vocal cord paralysis, the tumor was vagal paraganglioma and due to the procedure of surgery, 10th cranial nerve was sacrificed. The fact that we did not experience any serious complications is an indicator of our success in CBT surgery. Besides, no recurrence was detected in any of our patients is an additional successful result for us. According to the literature, the recurrence rate is $0.5-4 \%$ in in patients with CBT patients according to the literature.

Histologically, CBT consists of two types of cells. These are chief cells and sustentacular cells in characteristic alveolar or Zellballen pattern ${ }^{16,17}$ (Figure 6).

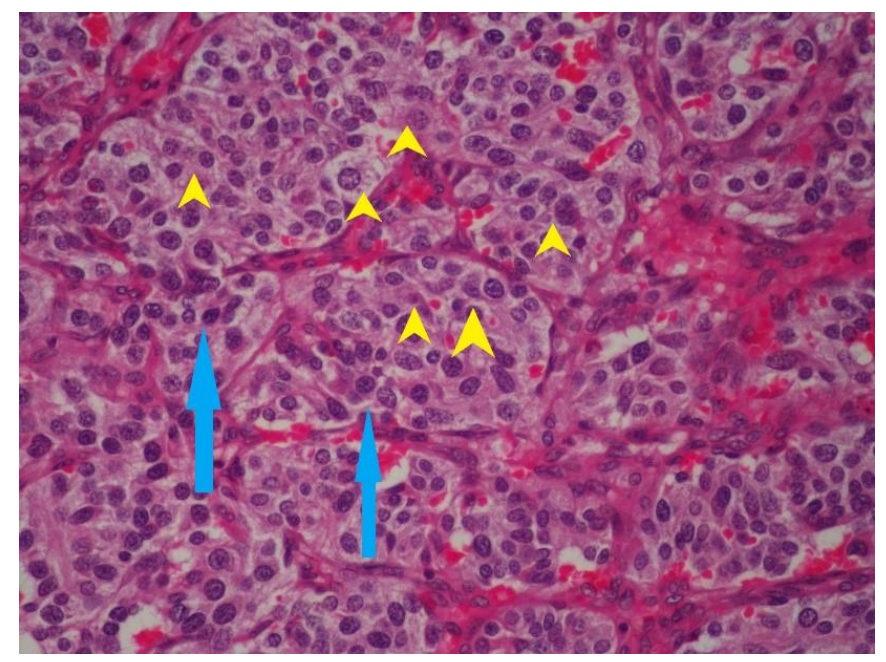

Figure 6: $\mathrm{x} 200$, Tumors have a characterisc alveolar or Zellballen pattern

The only criterion of malignancy is the presence of lymph node or distant metastasis. Reliable prediction of biological behavior of paragangliomas on the basis of histopathological features is very difficult. Although it has been proposed that variable histopathological parameters (nuclear pleomorphism, necrosis, vascular and perineural invasion, mitotic activity, cellularity, capsular invasion, Ki-67 immunoreactivity) can indicate a higher likelihood of aggressive behavior, this has not been universally accepted $^{18}$.In view of the histopathological features of the tumors, it could be accepted that our patients generally do not have a very aggressive tumor. In addition, no metastasis and malignant transformation was detected in any of our patients.

Two other important features about paragangliomas are that they can be familial and multicentric ${ }^{19,20}$. A familial origin should be suspected if other family members have paraganglioma, paragangliomas are multiple or the patient is young. It is known mutations in the succinate dehydrogenase and its subunit genes can lead to familial paraganglioma, and it is recommended patients with paraganglioma 
should be tested with genetic screening tests including whole-genome sequencing (WGS), whole-exome sequencing (WES) and targeted next-generation sequencing (NGS) with the idea of specific genetic mutations are related to malignant paraganglioma or positive genetic mutation may result in an earlier diagnosis of relatives of patients.However, there was no patient in our patient series that required a genetic study. Additionally, none of our patients had additional praganglioma according to abdominal screening. The fact that only abdominal screening was performed in our patient series could be discussed as a limitation of this study, because metaiodobenzylguanidin (MIBG) scintigraphy or CT /MRI including thorax and abdomen is a more valuable method to detect multicentric paraganliomas.

\section{CONCLUSION}

The surgery of carotid body tumors requires a certain amount of knowledge and experience. Additionally, this surgery is a team work. Establishing a team of Ear Nose Throat, Interventional Radiology or Interventional Neurology and Cardiovascular Surgery physicians will improve the success of surgery.

Manuscript was presented in 40th Turkish National Ear Nose Throth and Head \& Neck Surgery Congress,7-11 November 2018, Antalya, Turkey

Ethics Committee Approval: The study was approved by local Ethics Committee with the number "19.06.2017/ 08”.

Conflicts of interest: The authors have no conflict of interests to declare.

Financial Disclosure: The authors declared that this study has received no financial support.

\section{REFERENCES}

1. Luna MA, Pineda-Daboin K. Cysts and Unknown Primary and Secondary Tumours of the Neck, and Neck Dissection. In: Cardesa A, SlootwegPJ,Gale N, Franchi A, editors. Pathology of the Head and Neck. Berlin: Springer Verlag Berlin and Heidelberg GmbH Co; 2016. p.273.

2. Başel H, Odabaşı D, Hazar A, Ekim H. Strategies at the treatment and diagnosis of carotid Body Tumors. TürkiyeKlinikleri J Cardiovasc Sci. 2009; 21:13-8.

3. Sanghvi VD, Chandawarkar RY. Carotid body tumors. J SurgOncol. 1993;54:190-2.

4. Sykes JM, Ossoff RH. Paragangliomas of the head and neck. OtolaryngolClin North Am. 1986; 19:755-67.

5. Shamblin WR, ReMine WH, Sheps SG, Harrison EG Jr. Carotid body tumor (chemodectoma). Clinicopathologic analysis of ninety cases. Am J Surg. 1971; 122:732-9.

6. Arya S, Rao V, Juvekar S, Dcruz AK. Carotid body tumors: objective criteria to predict the Shamblin group on MR imaging. AJNR Am J Neuroradiol. 2008; 29: 1349-54.

7. Somasundar $\mathrm{P}$, Krouse $\mathrm{R}$, Hostetter $\mathrm{R}$, Vaughan R, Covey T. Paragangliomas:a decade of clinical experience. J SurgOncol. 2000; 74:286-90.

8. Sajid MS, Hamilton G, Baker DM; Joint Vascular Research Group. A multicenter review of carotid body tumour management. Eur J VascEndovasc Surg. 2007; 34:127-30.

9. Zhang TH, Jiang WL, Li YL, Li B, Yamakawa T. Perioperative approach in the surgical management of carotid body tumors. Ann Vasc Surg. 2012; 26:775-82.

10. Netterville JL, Reilly KM, Robertson D, et al. Carotid body tumors: A review of 30 patients with 46 tumors. Laryngoscope. 1995; 105: 11526.

11. Kakkos SK, Reddy DJ, Shepard AD, et al. Contemporary presentation and evolution of management of neck paragangliomas. J Vasc Surg. 2009; 49: 1365-73. 
12. Rao USV, Chatterjee S, Patil AA, Nayar RC. The "INT-EX Technique": Internal to External Approach in Carotid Body Tumour Surgery. Indian J SurgOncol. 2017; 8:249-52.

13. Fruhmann J, Geigl JB, Konstantiniuk P, Cohnert TU. Paraganglioma of the carotid body: treatment strategy and SDH-gene mutations. Eur J VascEndovasc Surg. 2013; 45: 431-6.

14. Kruger AJ, Walker PJ, Foster WJ, et al. Important observations made managing carotid body tumors during a 25-year experience. J Vasc Surg. 2010; 52:1518-23.

15. Gad A, Sayed A, Elwan H, et al. Carotid body tumors: a review of 25 years' experience in diagnosis and management of 56 tumors. Ann Vasc Dis. 2014; 7: 292-9.
16. Barnes L, Eveson JW, Reichart P, Sidransky D. World Health Organization Classification of Tumors.Pathology and genetics of head and neck tumours: Tumors of the paraganglionic system, chapter 8, 362-364; 2005.

17. Broes K, Vanderveken OM, Salgado R, et al. Atypical adenolymphoma and glomus caroticumtumour: a rare coincidence. B-ENT. 2012; 8:43-7.

18. Gnepp DR. Diagnostic Surgical Pathology of the Head and Neck, Second Edition. Saunders; 2009; p. 859-61.

19. Myssiorek D, Ferlito A, Silver CE, Rodrigo JP, Baysal BE, Fagan JJ, et al.Screening for familial paragangliomas. Oral Oncol. 2008; 44:532-7.

20. Álvarez-Morujo RJ, Ruiz MÁ, Serafini DP, et al. Management of multicentricparagangliomas: Review of 24 patients with 60 tumors. Head Neck. 2016; 38:267-76. 